\title{
Dairy systems study of the effects of contrasting spring grazing managements on pasture and animal production
}

\author{
G.J. BISHOP-HURLEY ${ }^{1}$, P.N.P. MATTHEWS ${ }^{1}$, J. HODGSON ${ }^{1}$, C. DAKE ${ }^{2}$ and C. MATTHEW ${ }^{1}$ \\ ${ }^{1}$ Department of Plant Science, Massey University, Palmerston North \\ ${ }^{2}$ Department of Agribusiness and Resource Management, Massey University, Palmerston North
}

\begin{abstract}
This paper reports the results of a dairying systems study at No. 4 Dairy, Massey University, investigating whether the benefits of contrasting spring grazing managements previously measured in small-scale experiments could be measured within the management constraints of a selfcontained farm production system. Management contrasts were early control (EC), in which pastures were closely controlled throughout spring and summer, with average pasture cover kept at approximately $2000 \mathrm{~kg} \mathrm{DM} / \mathrm{ha}$, and late control (LC), in which average pasture cover was increased to $2700 \mathrm{~kg} \mathrm{DM} / \mathrm{ha}$, allowing some reproductive growth through October and November before returning average pasture cover to $2000 \mathrm{~kg} \mathrm{DM} / \mathrm{ha}$ in December. Average pasture cover and pre- and post-grazing cover differences between treatments were achieved over late spring in all three years. However, average pasture cover during summer did not differ between treatments. Milksolids (MS) production per cow during the spring phase was higher for the LC treatment than for EC, but the differences disappeared over the December control phase and overall differences were small and inconsistent. The use of mechanical topping in December 1995/96 reduced the penalty to LC MS production experienced in previous years. Late control spring grazing management did not significantly increase pasture or MS production within the confines of a closed production system, contrary to the results of previous small-plot and paddock-scale experiments.
\end{abstract}

Keywords: dairy cow, dairy systems, Lolium perenne, milksolids production, pasture production, spring grazing management, Trifolium repens

\section{Introduction}

Traditionally, the emphasis in dairying systems has been on maintaining pasture quality in late spring through increased grazing pressure (speeding up the round and forage conservation) and sometimes topping. Recent studies have reported an increase in summer and autumn herbage production by allowing some reproductive development, followed by a period of control at the time of anthesis when seed-heads are immature and still palatable (late control), through effects on tiller population and size (da Silva et al. 1993, 1994; Hernández Garay 1995; Matthew et al. 1989). A series of small-plot and paddock-scale trials supported the hypothesis, suggesting late control can be achieved through grazing management, and animal performance could be enhanced as a consequence of sward conditions which lead to higher clover and total pasture growth rates in summer (da Silva et al. 1993, 1994). However, it remained to be seen whether the additional herbage produced could be converted into increased animal output or alternative management advantages within the constraints of a closed production system. This paper summarises the results of a dairy systems study carried out at No. 4 Dairy, Massey University to determine whether the benefits of late control can be measured in animal production.

\section{Experimental design}

Two 20-paddock perennial ryegrass-white clover dominant farmlets of 45 ha were each stocked with 120 spring calving Friesian cows in October 1993. Treatments were randomly allocated within pairs of paddocks between farmlets at the beginning of the trial which ran for three lactations until May 1996. Initially, cows were allocated to treatments balanced for age, calving date and herd test. Between years cows were retained on treatments and replacements, $20 \%$ and $25 \%$ for the 1994/95 and 1995/96 years respectively, were allocated to treatments balanced for calving date, liveweight and breeding index.

The first treatment, designated early control (EC), involved strict control of grazing throughout spring and summer, aiming for average pasture cover of approximately $2000 \mathrm{~kg} \mathrm{DM} / \mathrm{ha}$ and post-grazing residual of approximately $1500 \mathrm{~kg} \mathrm{DM} / \mathrm{ha}$. Spring pasture surplus was controlled by a conventional (20- to 25 -day) rotation and dropping paddocks out of the rotation for later conservation. Limits on average pasture cover in this treatment encouraged high levels of pasture utilisation 
by the cows in early lactation. Pastures in the second treatment (late control - LC) were allowed to develop some reproductive growth through October and November for removal in December. Average pasture cover target was $2700 \mathrm{~kg} \mathrm{DM} / \mathrm{ha}$, with post-grazing residual approximately $2000 \mathrm{~kg} \mathrm{DM} / \mathrm{ha}$ over spring. Average pasture cover was reduced to $2000 \mathrm{~kg} \mathrm{DM} / \mathrm{ha}$ in December by grazing to lower residuals while at the same time removing paddocks from grazing for immediate conservation.

Differences in average farm cover, animal condition and conserved feed created by the treatments in mid to late spring were carried forward into summer, autumn and winter. However, both farmlets were returned to a common management point by the planned start of calving (1 August) each year. This was defined as a target average pasture cover of $2000 \pm 100 \mathrm{~kg} \mathrm{DM} / \mathrm{ha}$ and an average cow condition score of $5.0 \pm 0.25$. With the exception of spring grazing, all management practices were balanced between the self-contained farmlets.

Plate meter readings of pasture cover were made weekly for all paddocks with ground level reference cuts and plate meter readings pre- and post-grazing from 5 representative "indicator" paddocks per treatment. Each week, pre-grazing herbage samples were clipped to grazing height from 2 paddocks per treatment for near infrared spectrophotometer (NIR) analysis of digestibility at AgResearch Grasslands, Palmerston North. Records were kept of supplements harvested from and fed out on each farmlet. Fortnightly herd tests were used to measure milk production. Unfasted liveweight and condition score were recorded monthly.

The data were evaluated by analysis of variance using the General Linear Models (GLM) procedure of SAS (SAS Institute Inc. 1988). Treatments were analysed as a completely randomised design (CRD) with paddocks and animals as replicates.

\section{Results}

Over the three years of the trial average pasture cover (Figure 1) ranged from 1200 to $1700 \mathrm{~kg} \mathrm{DM} /$ ha during winter and 2400 to $3800 \mathrm{~kg} \mathrm{DM} / \mathrm{ha}$ in summer (SEM 128). Average pasture cover was always higher on the LC farmlet than on the EC farmlet during spring. During summer 1995/96 pre-grazing pasture cover was greater for LC than EC ( $\mathrm{p}<0.05)$ (Table 1). Post-grazing pasture cover for LC exceeded EC by $1440 \mathrm{~kg} \mathrm{DM} / \mathrm{ha}(\mathrm{p}<0.10)$ in spring 1993/94.

Monthly herbage accumulation rates from indicator paddocks ranged from $5 \mathrm{~kg} \mathrm{DM} /$ ha/day in winter to over 100 (SEM 8.7) kg DM/ha/day in spring of 1995/
96 year (Figure 2). In 1993/94 and 1994/95 (SEM 7.95 and 4.72 , respectively), accumulation rate tended to be higher for LC, although the only significant difference was in autumn of 1995. In the final year (1995/96) neither treatment appeared to have an advantage, with the exception of LC in September 1995 when the differences approached significance $(\mathrm{p}<0.10)$.

In 1994/95 seasonal mean estimates of organic matter digestibility (OMD) were 76.7 and $77.9 \%$ (SEM 0.68) for spring, 73.9 and $73.8 \%$ (SEM 0.92) for summer, 74.2 and $75.0 \%$ for autumn (SEM 0.32) and 77.3 and $76.4 \%$ for winter (SEM 1.20) for EC and LC, respectively. In 1995/96 seasonal mean estimates of OMD were 74.5 and $75.1 \%$ (SEM 0.89) for spring, 70.0 and $70.2 \%$ (SEM 0.77) for summer and 73.9 and $70.9 \%$ for autumn (SEM 0.73) for EC and $L C$, respectively. Values did not differ significantly between treatments with the exception of autumn $1996(\mathrm{p}<0.05)$.

Treatment differences in milksolids (MS) production in 1993/94 were variable (Figure 3), with no extended period of advantage apparent to either treatment. In early spring 1994 significant differences were again apparent although treatment effects were not consistent. During the control phase in December MS production was higher on EC than LC, although this advantage was reversed towards the end of lactation. In the final year (1995/96) results were again variable.

During the first year (1993/94) treatment had no effect on liveweight or condition score (Table 2). In the second year (1994/95) EC cows were heavier and had

Table 1 Seasonal pre- and post-grazing pasture covers (kg $\mathrm{DM} / \mathrm{ha}$ ) and SEM for early and late control indicator paddocks over three years.

\begin{tabular}{|c|c|c|c|c|c|c|}
\hline \multirow[t]{2}{*}{ Season } & \multicolumn{2}{|c|}{----- Pre-grazing } & \multirow{2}{*}{ SEM } & \multicolumn{2}{|c|}{---- Post-grazing } & \multirow{2}{*}{ SEM } \\
\hline & $\begin{array}{l}\text { Early } \\
\text { control }\end{array}$ & $\begin{array}{l}\text { Late } \\
\text { control }\end{array}$ & & $\begin{array}{c}\text { Early } \\
\text { control }\end{array}$ & $\begin{array}{l}\text { Late } \\
\text { control }\end{array}$ & \\
\hline \multicolumn{7}{|l|}{$1993 / 94$} \\
\hline Spring & _ & - & - & 1,410 & 2,850 & $136+$ \\
\hline Summer & 3,310 & 3,190 & 366 & 2,470 & 2,250 & 368 \\
\hline Autumn & 1,810 & 2,320 & 243 & 1,690 & 1,560 & 520 \\
\hline \multicolumn{7}{|l|}{$1994 / 95$} \\
\hline Winter & - & 2,470 & 332 & 630 & 1,070 & 188 \\
\hline Spring & 2,430 & 2,420 & 284 & 1,880 & 2,170 & 243 \\
\hline Summer & 2,560 & 2,710 & 249 & 2,360 & 2,550 & 136 \\
\hline Autumn & 2,920 & 2,670 & 228 & 1,750 & 1,790 & 357 \\
\hline \multicolumn{7}{|l|}{$1995 / 96$} \\
\hline Winter & 2,160 & 1,880 & 110 & 1,050 & 1,110 & 153 \\
\hline Spring & 1,900 & 2,140 & 216 & 1,800 & 1,600 & 156 \\
\hline Summer & 2,930 & 3,740 & $198 *$ & 2,610 & 2,810 & 257 \\
\hline Autumn & 4,000 & 3,550 & 512 & 1,840 & 1,900 & 332 \\
\hline
\end{tabular}

For all tables: NS $=$ not significant, $+=\mathrm{P}<0.10,{ }^{*}=\mathrm{P}<0.05,{ }^{* *}=\mathrm{P}$ $<0.01,{ }^{* * *}=\mathrm{P}<0.001$ 
Figure 1 Average pasture cover ( $\mathrm{kg} \mathrm{DM} / \mathrm{ha}$ ) for early control and late control paddocks over three years. For all figures: early control.-- and late control --0--. Significant differences are indicated by $+p<0.10$ and ${ }^{*} p<0.05$.

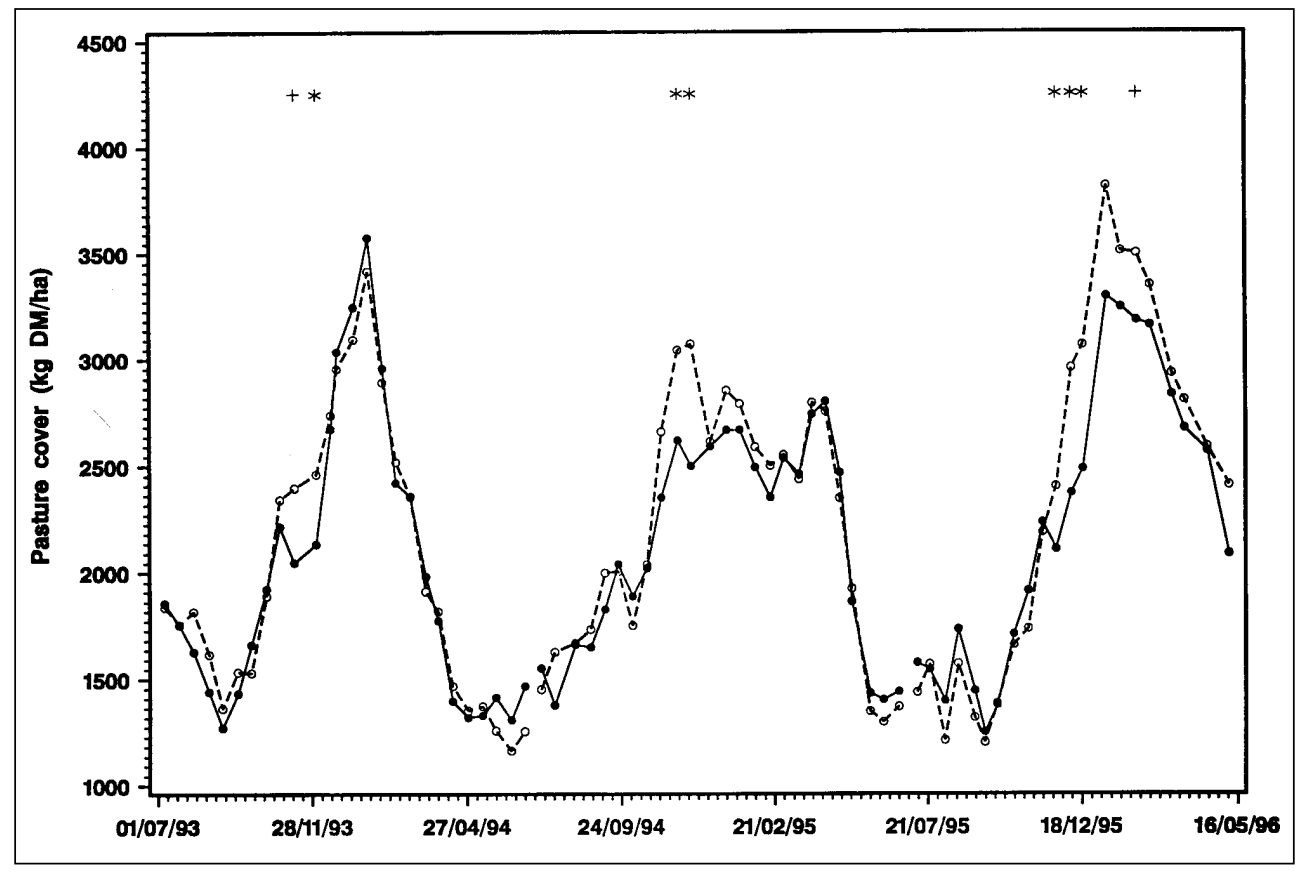

Figure 2 Effect of treatment on monthly herbage accumulation rate ( $\mathrm{kg} \mathrm{DM} /$ ha/day) in indicator paddocks over three years.

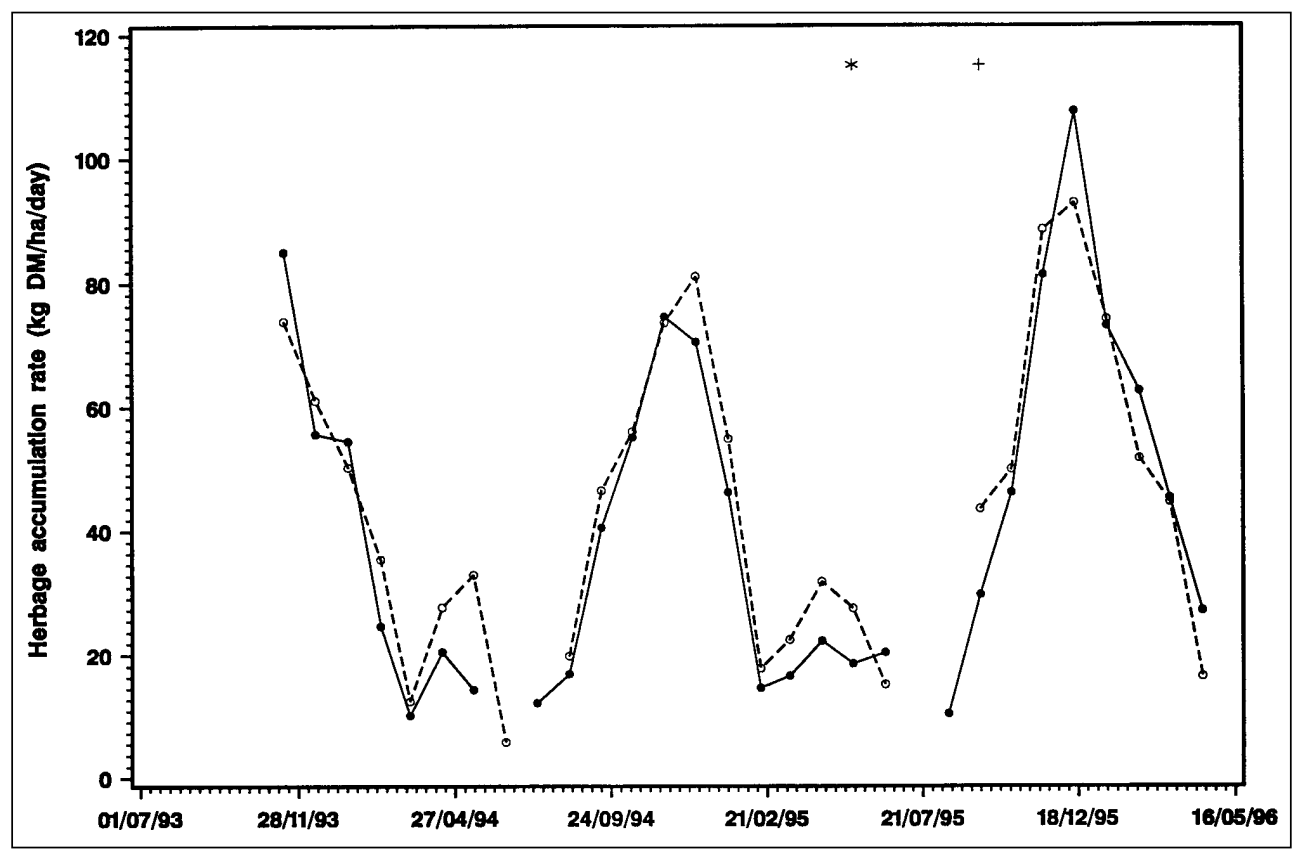


Figure 3 Mean daily milksolids production ( $\mathrm{kg} \mathrm{MS/cow/day)} \mathrm{for} \mathrm{early} \mathrm{control} \mathrm{and} \mathrm{late} \mathrm{control} \mathrm{herds} \mathrm{over} \mathrm{three}$ years, adjusted by using initial milksolids as covariate. Overall SEM was 0.025 .

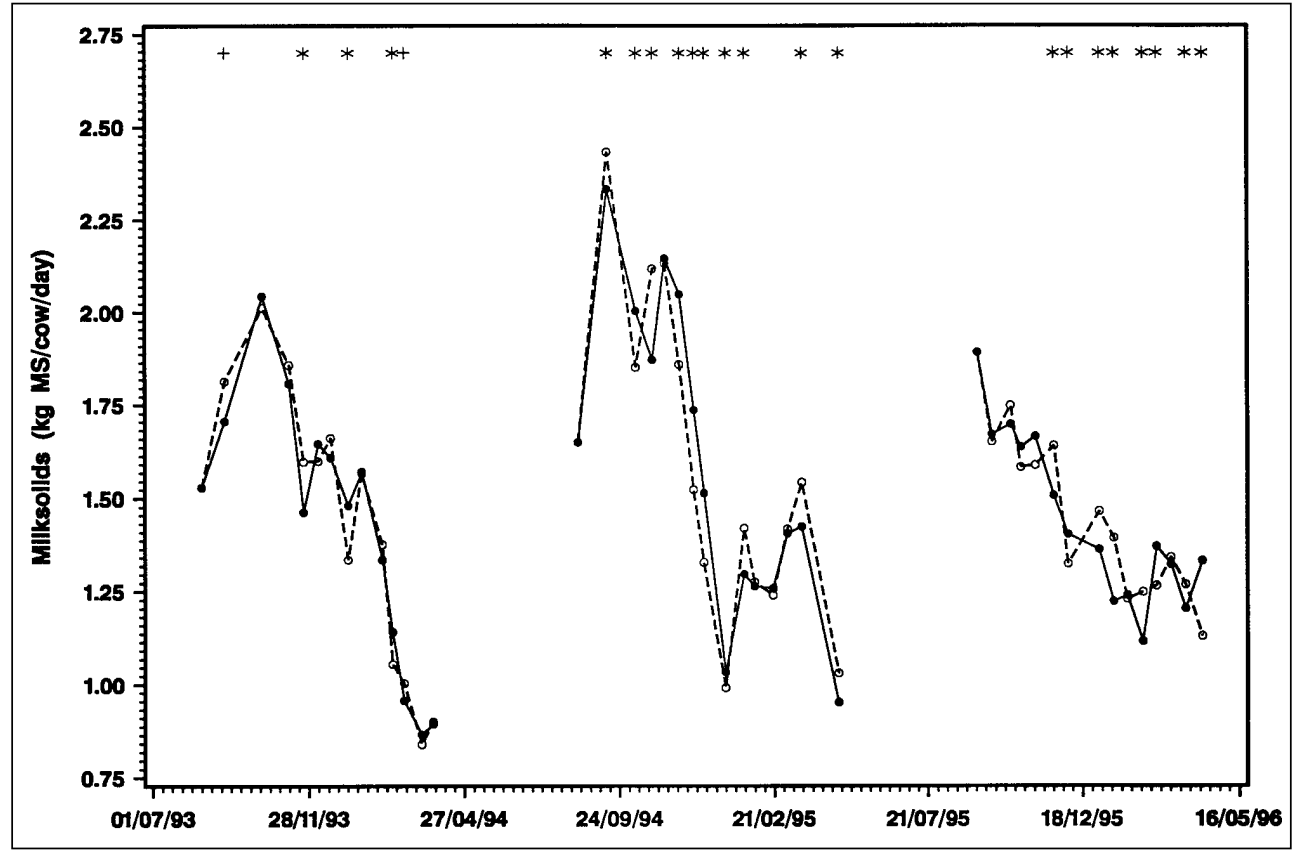

Table 2 Liveweight $(\mathrm{kg})$ and condition score values postcalving and at drying off over three years, adjusted by using initial liveweight and condition score as covariates.

\begin{tabular}{lcccccc}
\hline Year & $\begin{array}{c}-- \\
\text { Post- }\end{array}$ & Drying & \multicolumn{2}{c}{$\begin{array}{c}\text { Post- } \\
\text { calving }\end{array}$} & off & Drying \\
calving & off & \multicolumn{2}{c}{$\begin{array}{c}\text { Post- } \\
\text { calving }\end{array}$} & $\begin{array}{c}\text { Drying } \\
\text { off }\end{array}$ \\
\hline Liveweight & & & & & & \\
Early control & 465 & 488 & 474 & 505 & 448 & 466 \\
Late control & 460 & 488 & 473 & 492 & 430 & 464 \\
SEM & 5.22 & 2.44 & 2.86 & 3.02 & 2.10 & 2.60 \\
& NS & NS & NS & $* *$ & $* * *$ & NS \\
Condition score & & & & & & \\
Early control & 4.49 & 4.69 & 4.53 & 4.88 & 4.22 & 4.33 \\
Late control & 4.52 & 4.62 & 4.61 & 4.62 & 4.23 & 4.34 \\
SEM & 0.031 & 0.044 & 0.032 & 0.057 & 0.038 & 0.047 \\
& NS & NS & + & $* *$ & NS & NS \\
\hline
\end{tabular}

higher condition score than LC cows when dried off. However, LC cows tended to have a higher condition score after calving. In the final year (1995/96) EC cows were heavier than LC cows post-calving, although their condition scores were similar. The liveweight difference disappeared by drying off.

Both farmlets had a net inflow of supplements in all years (Table 3 ). The deficit was similar between
Table 3 Herbage conserved and supplements fed (kg DM/ ha) and supplement balance ( $\mathrm{kg} \mathrm{DM} / \mathrm{ha}$ ) over three years.

\begin{tabular}{lccc}
\hline Year & $\begin{array}{c}\text { Herbage } \\
\text { conserved }\end{array}$ & $\begin{array}{c}\text { Supplements } \\
\text { fed }\end{array}$ & Balance \\
\hline 1993/94 & & & \\
$\quad$ Early control & 1,185 & 1,825 & 640 \\
$\quad$ Late control & 1,025 & 1,881 & 856 \\
1994/95 & & & \\
$\quad$ Early control & 332 & 1,750 & 1,418 \\
Late control & 574 & 2,139 & 1,565 \\
1995/96 & & & \\
$\quad$ Early control & 274 & 1,368 & 1,094 \\
Late control & 117 & 2,139 & 2,022 \\
\hline
\end{tabular}

† Supplements fed; maize, silage and crop by-products.

treatments in the first two years (1993/94 and 1994/95) although over 50\% higher in 1994/95 than in 1993/94. In the first year slightly more supplements were harvested on EC than LC, but the opposite was the case in 1994/95. In the final year the deficit for LC was twice that of EC, the result of less forage conserved on LC and approximately $30 \%$ more supplements fed. 


\section{Discussion}

In practice it was more difficult than expected to maintain predetermined sward conditions based on average pasture cover and post-grazing residues. Average pasture cover differences between treatments were achieved over late spring every year (Figure 1). However, the extent and duration of the differences achieved were limited and were not reflected in pre-grazing covers, particularly in the first two years (Table 1). Treatment differences were not apparent until November, 4-6 weeks later than in previous experiments (da Silva 1994; Hernández Garay 1995). Recent work has shown that late control spring grazing management increases tiller population and size more after an extended spell of seed-head development (12 weeks) when compared to a shorter spell of 6 weeks (Hernández Garay 1995). In addition, the difference between treatments was less than the $700 \mathrm{~kg} \mathrm{DM} / \mathrm{ha}$ target. Average pasture covers were higher than the $2000 \mathrm{~kg} \mathrm{DM} / \mathrm{ha}$ and $2700 \mathrm{~kg} \mathrm{DM} /$ ha targets in spring, and EC pasture cover was closer to that of LC in previous experiments, particularly for 1995/96 (da Silva et al. 1994). It appears that the measurement method used reflected increasing dry matter content of pastures over summer compared with visual targets normally used in practice by farmers, and therefore influenced the absolute values measured.

In the first two years, there were no differences between treatments in average pasture cover and preand post-grazing herbage mass during summer. Average pasture covers were also similar in the summer of the final year, although pre-grazing pasture cover was higher on LC then EC (Table 1). Herbage accumulation rates were also similar (Figure 2), although in the first two years there appeared to be an advantage to LC, particularly in autumn. Previous small-plot and paddockscale experiments have shown increased summer and autumn pasture production after LC spring pasture management (da Silva et al. 1993, 1994).

LC management did not affect pasture quality (OMD) in spring or summer. Da Silva et al. (1994) showed individual cow performance was not affected during the "control phase" of reproductive growth on LC despite the higher proportion of grass stem and senescent material in those swards compared with EC swards.

The advantage in MS production per cow frequently changed between treatments (Figure 3) so that, overall, differences were small and inconsistent. Large differences in animal performance would not be expected, considering the marginal differences in pasture production achieved. LC cows were disadvantaged during the pasture control phase in December 1994/95, whereas mechanical topping was used in the 1995/96 year and limited the impact on milk production.
Liveweight and condition score differences between treatments were also small and inconsistent.

The high supplement use in the LC treatment relative to the EC treatment in the final year (1995/96) was considered essential to offset the lower liveweights of LC cows after winter and in an attempt to realise the $700 \mathrm{~kg} \mathrm{DM} / \mathrm{ha}$ cover difference required during a cold spring. A net inflow of supplements is typical for this type of dairy farm at the stocking rate used.

\section{Conclusions}

The pasture cover differences required for the LC treatment were not achieved during late spring (November-December), and as a consequence the response in animal performance was smaller than the results of previous small-plot and paddock-scale experiments suggested. Management constraints at the high stocking rate imposed contributed to the lack of differences achieved in spring pasture cover. Pasture control was best achieved through the combined use of the grazing animal and mechanical topping. The LC treatment did not significantly reduce forage digestibility.

Despite the lack of clear treatment differences in MS production, tight control of variability was achieved in this large systems trial, providing an objective basis for evaluation. Systems research of this type needs to include tight specifications and control of pre- and postgrazing pasture cover in addition to average pasture cover. More flexibility in stocking rate or use of supplements may be needed to establish spring pasture cover contrasts in future studies. During the course of this trial spring grazing management on dairy farms has tended towards that of LC management, with farmers operating grazing systems with higher average pasture covers through spring and being more likely to use mechanical means of controlling spring pasture quality (Matthews 1995).

\section{ACKNOWLEDGEMENTS}

The authors thank Associate Professor C.W. Holmes, the staff from Farms Administration, No. 4 Dairy Farm and the Department of Plant Science of Massey University for their assistance. This dairy systems trial was partially funded by the Dairying Research Corporation and their contribution to the project is gratefully acknowledged.

\section{REFERENCES}

da Silva, S.C.; Matthew, C.; Matthews, P.N.P.; Hodgson, J. 1993. Influence of spring grazing management 
on summer and autumn production of dairy pastures. Proceedings of the XVII International Grassland Congress: 859-860.

da Silva, S.C.; Hodgson, J.; Matthews, P.N.P.; Matthew, C.; Holmes, C.W. 1994. Effect of contrasting spring grazing management on summer-autumn pasture and milk production of mixed ryegrass-clover dairy swards. Proceedings of the New Zealand Society of Animal Production 54: 79-82.

Hernández Garay, A. 1995. Defoliation management, tiller density and productivity in perennial ryegrass swards. PhD Thesis, Massey University, 228pp.
Matthew, C.; Xia, J.X.; Hodgson, J.; Chu, A.C.P. 1989. Effect of late spring grazing management on tiller age profiles and summer-autumn pasture growth rates in a perennial ryegrass (Lolium perenne L.) sward. Proceedings of the XVI International Grassland Congress: 521-522.

Matthews, P.N.P. 1995. Grazing management principles and targets: a case study. Dairyfarming Annual 47: 171-174.

SAS, 1988: SAS user's guide, release 6.03 edition. Statistical Analysis System Institute. Cary, North Carolina, USA. 